Katarzyna Gmaj*

\title{
Polacy: największa grupa imigrancka w Norwegii
}

Poles: the largest immigrant group in Norway: The objective of this article is to present migration flows from Poland to Norway. It begins with the short description of Norway as an immigration country. Next, it discusses the growth of Polish community and its social and demographic characteristics. Poles are the largest immigrant group in Norway, standing at more than 100,000 people. A special attention is given to the unfavourable working conditions for Poles in the Norwegian labour market. The article concludes with a summary referring to the main findings and an attempt to outline potential directions for future research.

Słowa kluczowe: migracje, Norwegia, polscy migranci, polscy migranci w Norwegii, rynek pracy, wzory osiedleńcze

Keywords: migration, Norway, Polish migrants, Polish migrants in Norway, labour market, settlement patterns

* Doktor nauk humanistycznych, adiunkt na Wydziale Ekonomii i Zarządzania Uczelni Łazarskiegow Warszawie • k.gmaj@lazarski.edu.pl • https://orcid.org/oooo-0001-6860-1927

\section{Wstęp}

Celem opracowania jest opisanie migracji Polaków do Norwegii. Artykuł rozpoczyna się krótką prezentacją tego kraju jako kraju imigracyjnego. Następna część dotyczy formowania polskiej społeczności i jej charakterystyki społeczno-demograficznej. Ze względu na ograniczenia dotyczące objętość prezentowanego materiału spośród zagadnień zasługujących na szczególną uwagę przedstawione zostały niekorzystne uwarunkowania funkcjonowania Polaków na norweskim rynku pracy. Artykuł zakończony jest podsumowaniem odwołującym się do głównych ustaleń i próbą naszkicowania potencjalnych kierunków przyszłych badań.

Autorka opiera się na przeglądzie literatury dotyczącej migracji Polaków do Norwegii i oficjalnych danych statystycznych. Uwzględnia też rezultaty badań jakościowych i ilościowych przeprowadzonych $\mathrm{w}$ ramach projektu TRANS- 
FAM $^{1}$, w którym sama była liderem zadania nr 6 „Strategie osiedleńcze w Norwegii". Ponadto, $\mathrm{w}$ opracowaniu wykorzystane zostały obserwacje $\mathrm{z}$ letnich pobytów autorki jako visiting researcher w Instytucie NOVA (2018, 2019), Oslo Metropolitan University (wcześniej Oslo and Akershus University College of Applied Sciences).

Do lat 70. XX wieku Norwegia była krajem emigracyjnym, ale rozwój gospodarczy, którego doświadczyła po drugiej wojnie światowej, sprawil, że stopniowo zaczęła przyjmować imigrantów. Najpierw otworzyła się na swobodny przepływ pracowników pomiędzy krajami skandynawskimi, a w połowie lat 70. na nisko wykwalifikowanych pracowników z Pakistanu i Turcji. Wprowadzone z czasem restrykcje wobec obywateli krajów słabo rozwiniętych nie zatrzymały ich napływu. Zmienił się natomiast charakter migracji z pracowniczych na łączenie rodzin. Lata 80. i 90. to okres przyjazdów uchodźców z różnych stron świata. W latach 90. Norwegia wprowadziła też program kwot dla pracowników sezonowych z Europy Środkowej i Wschodniej, z którego korzystali głównie Polacy. Warto zauważyć, że do 2004 r. regulacje dotyczące swobodnego przepływu pracowników w ramach Europejskiego Obszaru Gospodarczego (EOG) miały bardzo ograniczony wpływ na imigrację do Norwegii. Dopiero rozszerzenie Unii Europejskiej (UE) w 2004 r. i 2007 r. spowodowało masowy napływ pracowników pochodzących z nowo przyjętych państw, chociaż okres przejściowy w dostępie do norweskiego rynku pracy, w którego trakcie obowiązywał wymóg uzyskania rocznego kontraktu na pełen etat, na warunkach porównywalnych do tych oferowanych norweskim pracownikom, zakończył się dopiero w roku $2009^{2}$.

Na początku 2019 r. imigranci oraz osoby urodzone w Norwegii, których oboje rodzice to imigranci, stanowiły $17,7 \%$ populacji Norwegii, czyli ponad 944 tys. ${ }^{3}$. W tym sami imigranci to ponad 765 tys., a ich potomkowie ponad 179 tys. Polacy są największą grupą imigrancką, liczącą według oficjalnych norweskich statystyk ok. 99 tys. $z$ dodatkowymi 13 tys. osób, które urodziły się w Norwegii i mają oboje rodziców Polaków, oraz 6 tys. - jednego polskiego rodzica4 ${ }^{4}$ Uwzględnić trzeba

1 Projekt TRANSFAM - Doing family in transnational context. Demographic choices, welfare adaptations, school integration and every-day life of Polish families living in Polish-Norwegian transnationality finansowany ze środków funduszy norweskich, $\mathrm{w}$ ramach programu „Polsko-norweska współpraca badawcza” realizowanego przez Narodowe Centrum Badań i Rozwoju w ramach Norweskiego Mechanizmu Finansowego na lata 2009-2014 w ramach kontraktu nr Pol-Nor/197905/4/2013. Więcej na jego temat przeczytać można na stronie www.transfam.socjologia.uj.edu.pl.

2 M.L. Baba, C. Dahl-Jørgensen, Work migration from Poland to Norway: A new institutional approach, „iNtergraph: journal of dialogic anthropology” 2010, nr 2(2).

3 Przywołane dane pochodzą z bazy danych Norweskiego Urzędu Statystycznego - Statistics Norway, https://www.ssb.no.

${ }^{4}$ Do tego doliczyć można jeszcze ponad 2,5 tys. osób urodzonych w Norwegii, które mają przynajmniej jednego polskiego dziadka oraz 0,3 tys. urodzonych poza Norwegią, których jeden z rodziców pochodzi z Polski, a drugi urodził się w Norwegii. 
jeszcze około 30 tys. pracowników przebywających co roku przez okres krótszy niż sześć miesięcy, którzy są zarejestrowani jako osoby niebędące rezydentami, ale pracujące w Norwegii. Aby przybliżyć się do całkowitej liczby Polaków, należy jeszcze wziąć pod uwagę tych, którzy oficjalnie przebywają w celach turystycznych, ale podejmują nierejestrowaną pracę. Określenie, ilu ich jest, to jednak ryzykowne zadanie, ponieważ jako obywatele UE przy wjeździe do Norwegii nie potrzebują wiz. Pod względem liczebności zaraz za Polakami sytuują się Litwini - niemalże 45,5 tys. i Somalijczycy - blisko 43 tys., oraz Szwedzi - prawie 39 tys. Warto też zwrócić uwagę, że wśród osób, które urodziły się w Norwegii, ale które mają imigranckie pochodzenie ${ }^{5}$, najwięcej ma rodziców z Pakistanu (ponad 17 tys.) i Somalii (ponad 14 tys.), a zaraz za nimi z Polski (ponad 13 tys.)

\section{Formowanie się polskiej społeczności}

Nieliczni Polacy osiedlali się w Norwegii już w XIX wieku. Jednak początki tworzenia się polskiej społeczności wiążą się z migracją kilku tysięcy polskich uchodźców politycznych w latach 80 . XX wieku. Lata 90. to z kolei okres napływu głównie pracowników sezonowych, którzy przybywali na podstawie dwustronnych umów o tymczasowej pracy w rolnictwie. Jednak dopiero po wstąpieniu Polski do UE liczba Polaków zaczęła dynamicznie wzrastać 7 . Przedstawiając ich geograficzne rozproszenie, należy stwierdzić, że ponad połowa mieszka w czterech okręgach znajdujących się w południowej części kraju: Oslo, Akershus, Rogeland, Hordaland. Reszta rozsiana jest po całej Norwegii ${ }^{8}$. Co ciekawe, Polacy to grupa imigrantów z najwyższym odsetkiem osób mieszkających na obszarach słabo zaludnionych ${ }^{9}$.

Od roku 2010 do roku 2019 z 6 tys. do prawie 63 tys. wzrosła liczba Polaków mieszkających w Norwegii przez okres pięciu lat i więcej (wykres 2), co stanowi blisko połowę wszystkich Polaków. Podobnie sukcesywnie zwiększała się liczba polskich dzieci (osoby poniżej 16. roku życia). Na początku 2019 r. było ich po-

${ }^{5}$ Imigranckie pochodzenie definiuje się jako posiadanie obojga rodziców i czwórki dziadków urodzonych poza Norwegią.

6 Bazy danych Statistics Norway.

7 K. Gmaj, K. Iglicka, The Story of the Icy Paradise: Polish Migration to Norway after the EU Enlargement (2004) in the Light of Research and Statistical Data, „CBU International Conference Proceedings” 2018, Vol. 6, https://doi.org/10.12955/cbup.v6.1149; K. Iglicka, K. Gmaj, A. Wierzejski, Contextualizing Polish Migration to Norway in the light of theory, statistical data and research findings [w:] Transnational Polish families in Norway: Social capital, integration, institutions and care, eds. K. Slany, P. Pustulka, E. Guribye, M. Ślusarczyk, Peter Lang, Frankfurt am Main, New York 2018, https://doi.org/10.3726/978-3-653-06594-7.

${ }^{8}$ Na podstawie bazy danych Statistics Norway.

9 K.R. Tronstad, M. Nygaard, M. Bask, Accumulation of welfare problems among immigrants in Norway, NIBR, OsloMet, Oslo 2018, s. 31. 
Wykres 1. Polscy imigranci oraz osoby urodzone w Norwegii, których rodzice pochodzą z Polski, lata 2003-2019

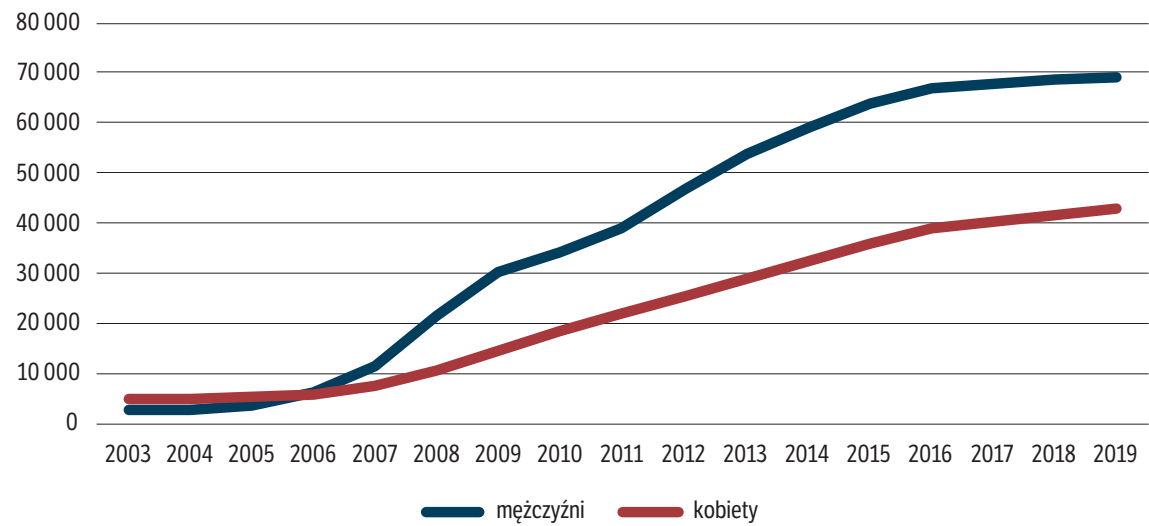

Źródło: na podstawie baz danych Statistics Norway.

Wykres 2. Polacy mieszkający w Norwegii powyżej 5 lat (stan na 1 stycznia)

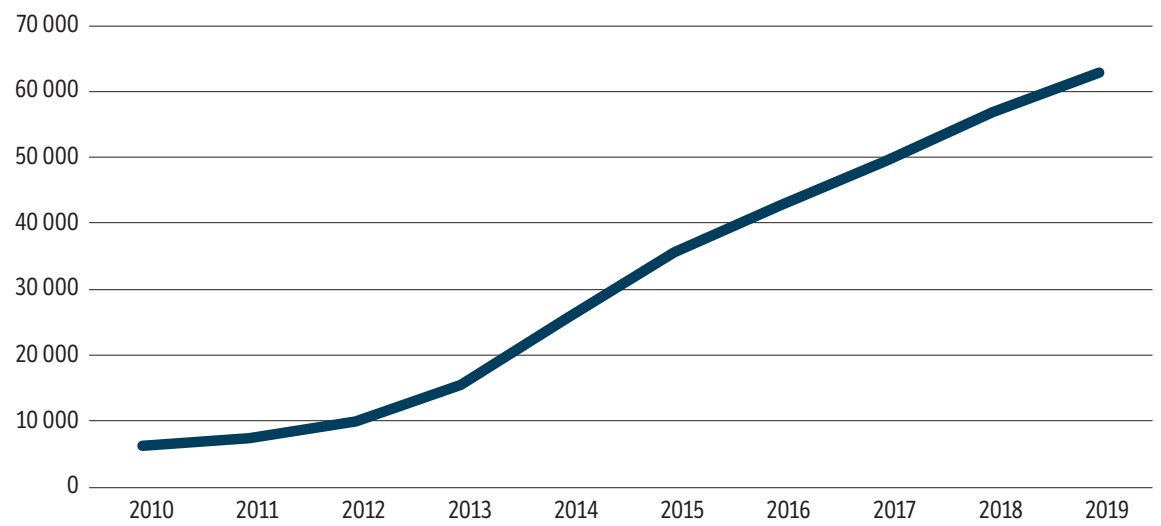

Źródło: jak pod wykresem 1.

nad 19 tys. (wykres 3). Dane te obejmują dzieci, które przyjechały do Norwegii, oraz te, które się w niej urodziły. Natomiast wykres 4 przedstawia ile dzieci co roku przychodziło na świat.

Od 2006 r. polscy obywatele stanowią najliczniejszą grupę cudzoziemców wskazujących przyjazd do rodziny jako podstawę ich pobytu w Norwegii ${ }^{10}$.

${ }^{10}$ W przypadku obywateli Polski (jako państwa należącego do EOG) informacja ta podawana jest przy rejestracji zezwolenia na pobyt w Norwegii. 
Wykres 3. Liczba polskich dzieci w Norwegii (polscy obywatele, poniżej 16. roku życia, stan na 1 stycznia)

25000

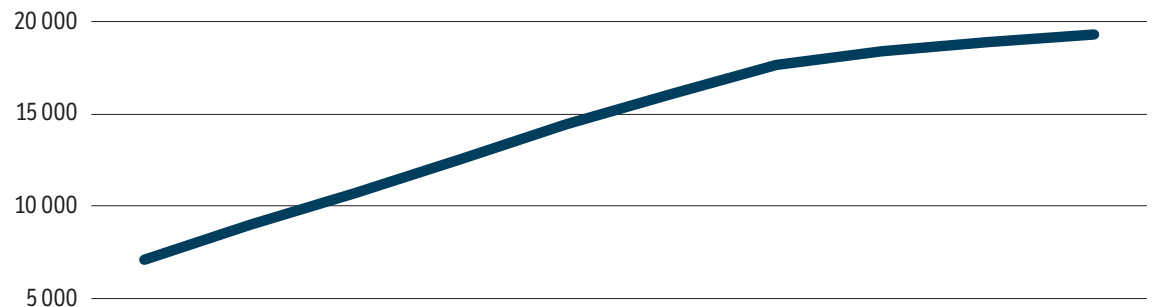

0

$\begin{array}{llllllllll}2010 & 2011 & 2012 & 2013 & 2014 & 2015 & 2016 & 2017 & 2018 & 2019\end{array}$

Źródło: jak pod wykresem 1.

\section{Wykres 4. Urodzenia żywe wśród matek urodzonych w Polsce*}

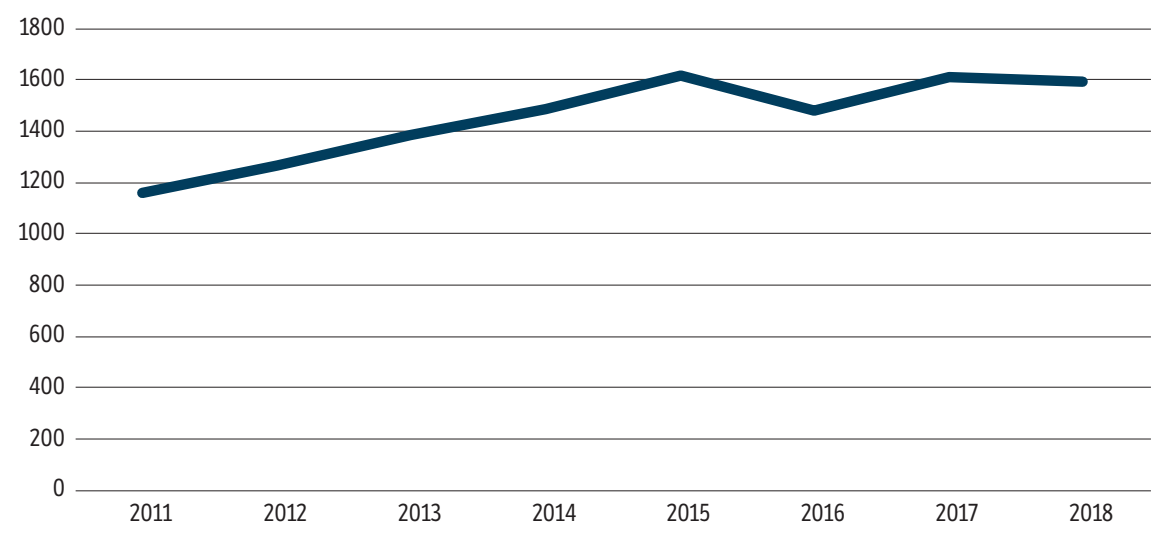

* Gdy rodzice pochodzą z różnych krajów, pod uwagę bierze się kraj pochodzenia matki, gdy ojciec dziecka jest Norwegiem urodzenie nie jest uwzględnione w tej statystyce.

Źródło: jak pod wykresem 1.

Wyjątek to 2017 r., kiedy Polaków wyprzedzili obywatele Syrii. Warto jednak zwrócić uwagę, że po rekordowym 2013 r. liczba tych wskazań spada (wykres 5.).

Podsumowując, powyższe statystki wskazują, że czasowa migracja Polaków przybiera formę długotrwałego pobytu. Dominujący po 2004 r. wzór czasowych migracji podejmowanych przeważnie przez mężczyzn uzupełniany jest przez migracje rodzinne. $\mathrm{W}$ tym kontekście rysuje się więc podobieństwo ze wzorami 


\section{Wykres 5. Migracje rodzinne z Polski do Norwegii, 2004-2018}

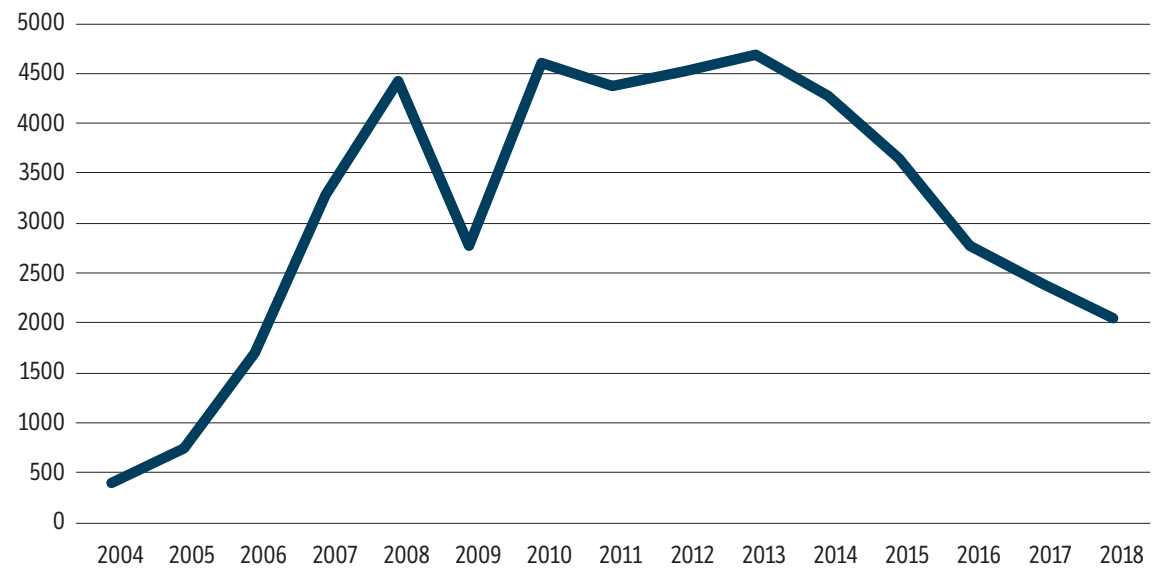

Źródło: Norweski Dyrektoriat do spraw Imigracji (UDI), https://www.udi.no (lata 2014-2018) i lata wcześniejsze UDI za E. Thorud, L. Stabbetorp, T. Galloway, K. Hårstad-Fonn, International Migration 2013-2014IMO report for Norway, Norwegian Ministry of Education and Research, Norwegian Ministry of Children, Equality and Social Inclusion, Norwegian Ministry of Justice and Public Security, Norwegian Ministry of Labour, 2014, s. 16, pdf.

obserwowanymi w Wielkiej Brytanii i Irlandiii ${ }^{11}$. Jon Horgen Friberg, badając Polaków w Norwegii, wyróżnił trzy fazy migracji ${ }^{12}$. Pierwszą z nich charakteryzują plany powrotu do domu w bliskiej przyszłości. Drugą powtarzające się podróże między oboma krajami, przy czym ta przedłużająca się tymczasowość związana jest z możliwościami podjęcia pracy. Ostatnia faza - osiedlenie - to sprowadzenie rodziny i przeniesienie gospodarstwa domowego do Norwegii. Nie wszyscy migranci przechodzą cały opisany wyżej cykl.

To, że analizowanie migracji Polaków do Norwegii w kategoriach migracji zarobkowych czy swobodnego przepływu siły roboczej jest niewystarczające i że procesy migracyjne i adaptację polskich migrantów lepiej rozpatrywać jest w kontekście różnych stadiów procesu migracyjnego niż różnych kategorii migrantów, potwierdzają także badania przeprowadzone w trakcie realizacji projektu TRANSFAM ${ }^{13}$. Materiał jakościowy wskazuje, że typowa migracja

${ }^{11}$ K. Iglicka, Powroty Polaków po 2004 roku. W pętli pułapki migracji, Scholar, Warszawa 2010; A. White, Polish Families and Migration since EU accession, Policy Press, Bristol 2011

12 J.H. Friberg, Culture at work: Polish migrants in the ethnic division of labour on Norwegian construction sites, „Ethnic and Racial Studies” 2012, Vol. 35 (11), https://doi.org/10. 1080/01419870.2011.605456.

${ }^{13}$ K. Gmaj, Settling in Norway? The case of Polish migrants and their families, „Myśl Ekonomiczna i Polityczna” 2016, nr 2; K. Gmaj, „Oswajanie” Norwegii: wzory osiedleńcze polskich 
osiedleńcza, tzn. planowana migracja całej rodziny w celu zmiany miejsca do życia, to raczej wyjątkowa sytuacja ${ }^{14}$. Częściej obserwowanym wzorem było nieplanowane i stopniowe osiedlanie całej rodziny, zwykle zaczynające się od jednej osoby, która wyjeżdżała "na jakiś czas” do pracy. Gdy rozłąka stawała się trudna do zniesienia, też „na jakiś czas” ściągano członków rodziny. Wraz z przedłużaniem pobytu dzieci zaczynały uczęszczać do norweskich przedszkoli i szkół. Zatem osoby, które początkowo określić można było jako migrantów cyrkulacyjnych albo krótkookresowych, „zapuszczały korzenie” w Norwegii. Podobnie rodziny, które początkowo zdecydowały się na wspólny wyjazd tylko na ograniczony czas, w związku z możliwościami zatrudnienia jednego z małżonków. Wraz z przedłużającym się kontraktem czy znalezieniem stałego zatrudnienia, ostatecznie zostawały dłużej niż zakładały. Zdecydowanych planów osiedleńczych od początku swojego pobytu w Norwegii nie mieli także migranci, którzy wyemigrowali bez zobowiązań rodzinnych. Partnerów życiowych - Polaków - poznali w Norwegii bądź sprowadzili ich z Polski. W związkach pojawily się dzieci, które zaczęły uczęszczać do norweskich placówek, i pobyt w Norwegii wydłużał się. Wyjątek stanowiła rodzina polsko-norweska, która zdecydowała się na stałe osiedlić w Norwegii, gdy starsze dziecko osiągnęło wiek szkolny. Jako jeden $\mathrm{z}$ najistotniejszych powodów mieszkania z rodziną w Norwegii rozmówcy wymieniali uzyskanie równowagi między pracą i życiem rodzinnym. Poczucie bezpieczeństwa ekonomicznego i przewidywalność to argumenty przemawiające za pozostaniem na emigracji, podobnie jak przekonanie, że dzieci w Norwegii będą miały lepsze szanse niż w Polsce ${ }^{15}$. Na uwagę zasługują też wyniki ankiety internetowej, przeprowadzonej także $\mathrm{w}$ ramach projektu TRANSFAM, w maju i czerwcu 2015 r. ${ }^{16}$. Osoby, które planowały zostać w Norwegii na stałe, czyli

migrantów w Norwegii, „Studia Migracyjne - Przegląd Polonijny” 2018, nr 1(167), https:// doi.org/10.4467/25444972smpp.18.008.8917.

${ }_{14}$ Analizie poddano wywiady z 24 osobami, które mieszkały w Norwegii wraz z rodzinami. Dziesięć z nich to wywiady przeprowadzone przy użyciu kombinacji technik biograficznej i narracyjnej, z których sześć to wywiady indywidualne, a cztery to rozmowy z oboma małżonkami. Odbyły się zimą i wiosną 2014 r. w Oslo i okolicach w ramach zadania 2. „Rodziny migranckie w Norwegii/struktury relacji władzy i negocjacji wartości i norm w rodzinach transnarodowych" (lider: Magdalena Ślusarczyk). Pozostałe osiem to wywiady ustrukturyzowane przeprowadzone latem 2014 r. z dziesięcioma imigrantami z Polski mieszkającymi w miejscowościach należących do okręgów Vest Agder i Aust Agder. Materiał zebrano w trakcie realizacji zadania 3. „Kapitał społeczny polskich imigrantów w Norwegii” (lider: Eugene Guribye).

${ }_{15}$ K. Gmaj, Settling in Norway?, op. cit.; K. Gmaj, „Oswajanie” Norwegii, op. cit.

16 W ankiecie wzięło udział 648 osób, z których 633 żyło w formalnych i nieformalnych związkach, 15 określiło się jako samodzielnie wychowujące dzieci. Więcej informacji na jej temat znaleźć można w: L. Huang, M. Kochowicz, E. Krzaklewska, P. Pustulka, TRANSFAM Web-survey on Polish families living in Polish-Norwegian transnationality Documentation of design, variables and measures, 2015, http://www.transfam.socjologia.uj.edu.pl; L. Huang, 
połowa respondentów, oraz te, które nie podjęły jeszcze decyzji (35\%), zapytane zostały o powody, dla których chciałyby zostać. Można było wybrać więcej niż jeden argument $\mathrm{z}$ gotowej listy. Prawie $2 / 3$ pytanych wskazało lepsze warunki pracy, połowa brak perspektyw w Polsce. Wyższy standard życia w Norwegii wskazała połowa respondentów, a prawie co czwarty to, że dzieci rozpoczęły naukę w Norwegii.

Relacje polskich dzieci i ich rodziców wskazywały, jak istotną rolę w przekazywaniu norm i wartości norweskiego społeczeństwa odgrywał system edukacji ${ }^{17}$. Warto przy tym zauważyć, że stosunki między uczniami i nauczycielami nie są tak zhierarchizowane, jak w polskich szkołach. Przedszkola i szkoły pośrednio przyczyniały się do integracji rodziców. Dorośli kontaktowali się z pracownikami tych placówek, a także z innymi rodzicami. Chociaż stosunki były powierzchowne, a czasem odbierane nawet jako wymuszone, stawały się rutyną bycia rodzicem w Norwegii. Poza angażowaniem w codzienność szkolną i przedszkolną dorośli angażowali się w dodatkowe zajęcia sportowe dzieci, lekcje języka polskiego itp., stopniowo zakorzeniając się w Norwegii ${ }^{18}$.

$\mathrm{W}$ podtrzymaniu znajomości języka polskiego oraz w przekazaniu polskiej kultury rodziców wspierały prowadzone przez stowarzyszenia tzw. szkoły polskie, oferujące naukę przeważnie w systemie sobotnim. Działały jeszcze przed rozszerzeniem UE, ale wraz z napływem większej liczby Polaków wciąż powstają nowe. W Oslo działa także szkoła przy ambasadzie RP. Tam, gdzie trudno było zorganizować lekcje języka i kultury polskiej, w pewien sposób zastępowała je katecheza po polsku. Wspomnieć też trzeba o polskim harcerstwie w Norwegii, które jest częścią norweskiego ruchu skautowego Norges KFUK-KFUM. Wszystkie aktywności służące podtrzymywaniu polskości oferowane dzieciom wiążą się z dużym zaangażowania rodziców. Stanowią też konkurencję dla innych zajęć dodatkowych czy zwykłej zabawy i lenistwa. Czasem rodziny pokonują znaczne odległości, aby na nie dotrzeć.

Osiedlając się w Norwegii, Polacy radykalnie zmieniają tryb życia ${ }^{19}$. Nie są przy tym wolni od napięć związanych z różnicami kulturowymi i nieporozumie-

E. Krzaklewska, P. Pustulka, Young Polish migrants in Norway: Education, work and settlement choice, „Tidsskrift For Ungdomsforskning” 2016, Vol. 16(1).

17 M. Ślusarczyk, R. Wardhal, S. Strzemecka, Polish children and their parents adapting to new school reality in Norway [w:] Transnational Polish families in Norway: Social capital, integration, institutions and care, eds. K. Slany, P. Pustulka, E. Guribye, M. Ślusarczyk, Peter Lang, Frankfurt am Main, New York 2018, https://doi.org/10.3726/978-3-653-06594-7. Integracja dzieci i młodzieży stanowiła w projekcie TRANSFAM część zadania 7. „Integracja i reintegracja polskich dzieci w szkole”. Przewijała się też w pozostałych zadaniach.

18 K. Gmaj, „Oswajanie” Norwegii, op. cit.

19 J. Bell, M. Bivand Erdal, Transnational family life among Polish migrants in Norway: Limited, but enduring transnational ties?, „Studia Migracyjne - Przegląd Polonijny”, 2015, Vol. 3; K. Gmaj, Settling in Norway?, op. cit.; K. Gmaj, „Oswajanie” Norwegii, op. cit. 
niami co do wartości i norm zachowań obowiązujących w polskim i norweskim społeczeństwie. Najbardziej jaskrawym tego przejawem jest niepokój rodziców przed zainteresowaniem ze strony norweskiej instytucji zajmującej się ochroną dzieci - Barneverne. Interwencja może skończyć się odebraniem i przekazaniem dzieci do rodziny zastępczej, a powody takiego biegu zdarzeń bywają niezrozumiałe dla polskich rodziców ${ }^{20}$.

Na uwagę zasługuje kwestia przyjmowania przez Polaków obywatelstwa norweskiego. Wykres 6 przedstawia liczbę naturalizacji w latach 2004-2018. Być może niewielka ich liczba związana jest z tym, że po 5 latach przebywania w Norwegii obywatele państw należących do EOG nabywają prawo do stałego pobytu, a z nim prawo do zamieszkania i pracy na stałe oraz dodatkową ochronę przed wydaleniem ${ }^{21}$. Zdobycie obywatelstwa wiąże się natomiast z koniecznością kosztownej nauki języka norweskiego ${ }^{22}$.

\section{Wykres 6. Naturalizacja w Norwegii osób z wcześniejszym polskim obywatelstwem}

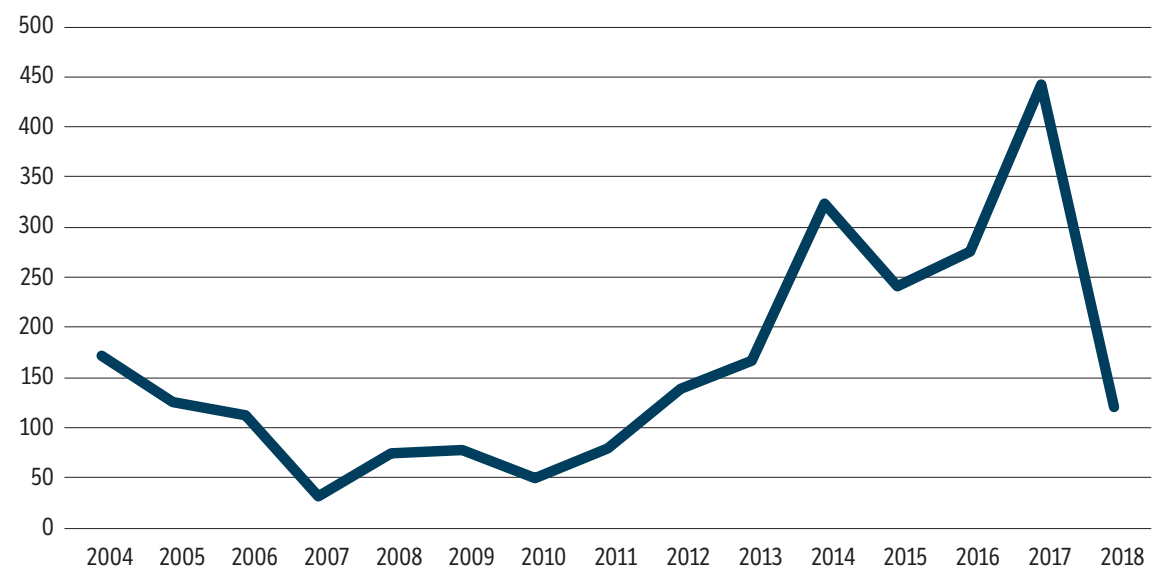

Źródło: jak pod wykresem 1.

20 M. Sokól-Rudowska, Us among them: A study of the contemporary Polish emigration to Norway, „Studia Humanistyczne AGH” 2013, t. 12/1, https://doi.org/10.7494/human.2013.12.1.9; R. Waerdahl, Integration and re-integration of Polish children in school: Part 1. Inclusion of Polish children in Norwegian schools (WP7 Working Report), 2015, http://www. transfam.socjologia.uj.edu.pl; J. Godzimirski, M. Stormowska, K. Dudzińska, Nowe diaspory w Europie i zarządzanie migracją: Przypadek Polaków w Norwegii, Polski Instytut Spraw Międzynarodowych, Instytut Studiów Politycznych Polskiej Akademii Nauk, Norweski Instytut Spraw Międzynarodowych, Warszawa 2015.

${ }^{21}$ Informacja przytoczona za oficjalną stroną Norweskiego Dyrektoriatu do Spraw Imigracji.

${ }^{22}$ Od 1 stycznia 2017 r. przy staraniu się o obywatelstwo obowiązuje wymóg zdania egzaminu z języka (norweskiego lub sami) na poziomie A2 oraz z wiedzy obywatelskiej, ibidem. 


\section{Wykres 7. Migracja netto obywateli polskich do Norwegii}

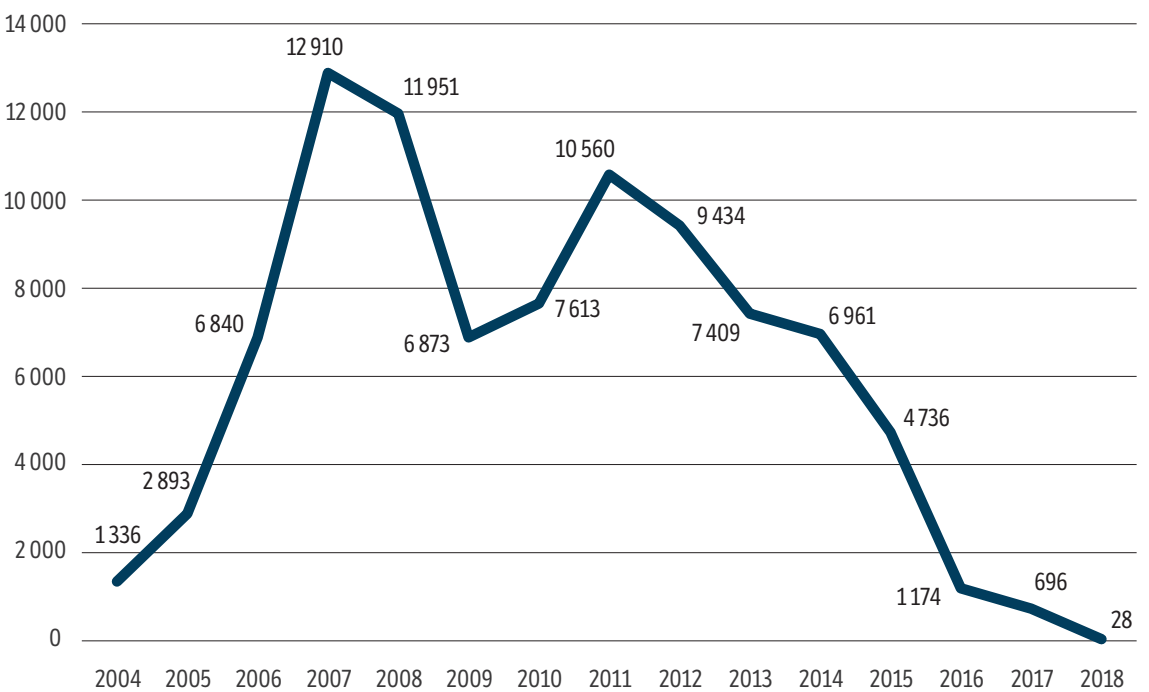

Źródło: jak pod wykresem 1.

\section{Wykres 8. Migracje obywateli polskich do i z Norwegii}

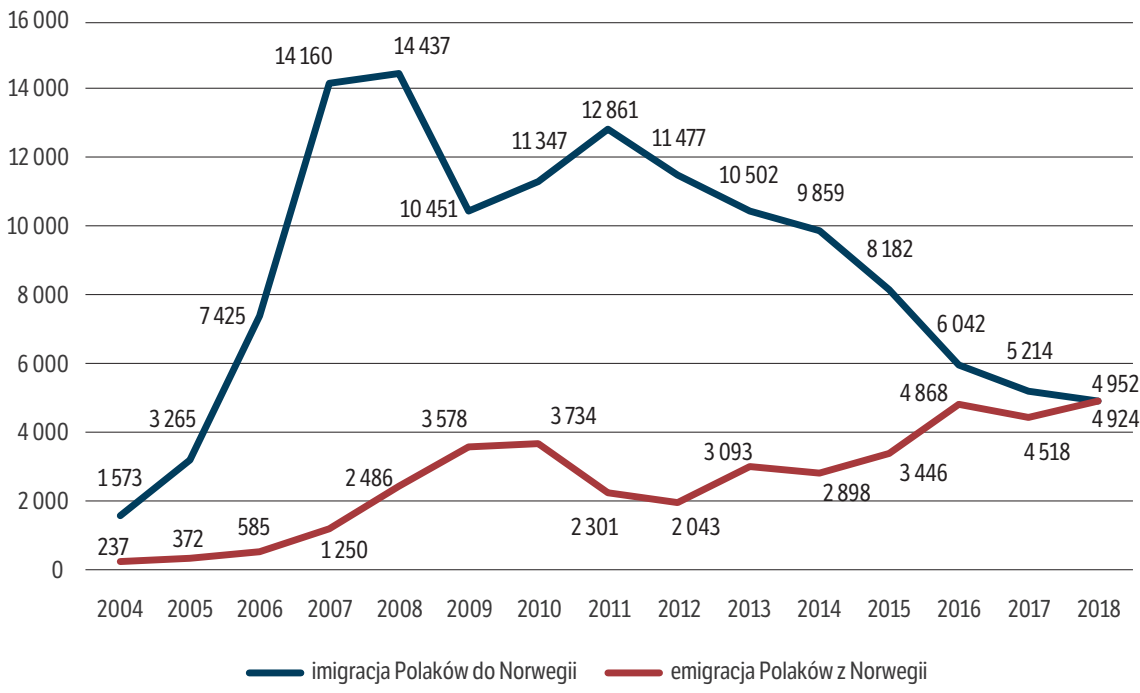

Źródło: jak pod wykresem 1. 
Na zakończenie tej części artykułu warto przyjrzeć się migracji netto, czyli różnicy w liczbie obywateli polskich przyjeżdżających do Norwegii i wyjeżdżających z tego kraju (wykresy 7 i 8). Bilans wciąż jest dodatni - więcej Polaków przyjeżdża do Norwegii niż z niej wyjeżdża. W latach 2004-2007 bilans rósł, w kolejnych spadał, aby od 2009 do 2011 r. znowu rosnąć. Jednak od 2011 r. konsekwentnie maleje. W 2018 r. wyniósł zaledwie 28 osób. W roku, w którym był najwyższy (2007), sięgnął prawie 13 tys. Rozpiętość jest ogromna.

Interesujące są także zmiany obserwowane w liczbie wskazań na pracę jako podstawę rejestracji pobytu w Norwegii. W 2012 r. takich wskazań było ponad 15,5 tys. Przez kolejne lata ich liczba spadała, aby w 2018 r. wynieść około 7 tys., czyli ponad dwa razy mniej ${ }^{23}$. Warto postawić pytanie, czy państwo norweskie będzie mogło w kolejnych latach oczekiwać tego, że Polacy dalej będą uzupełniać braki w lokalnej sile roboczej? Działacze polskich stowarzyszeń zaczynają odczuwać ze strony władz norweskich większe zainteresowanie procesem integracji imigrantów z Polski i ich planami na przyszłość ${ }^{24}$.

\section{Charakterystyka demograficzna i społeczna Polaków w Norwegii}

Przekrój zawodowy Polaków w dużym stopniu odzwierciedla popyt na siłę roboczą. Zapotrzebowanie na pracowników związane jest z segmentacją rynku pracy, którą analizować można w kontekście zmian społecznych i strukturalnych, a w szczególności restrukturyzacji sektorów pracochłonnych, takich jak $n$ p. budownictwo ${ }^{25}$. Polacy w Norwegii pracują głównie w następujących sektorach gospodarki: budownictwo, wytwarzanie energii elektrycznej, zaopatrzenie w wodę, kanalizacja, gospodarka odpadami; produkcja; rekrutacja pracowników i zapewnienie personelu. Pracują też w służbie zdrowia - jako personel średniego i wyższego szczebla, w edukacji - poczynając od przedszkoli, a na uniwersytetach kończąc, oraz w szeroko pojętych usługach. Pracują jako inżynierowie i urzędnicy. Jednak najczęściej wykonują prace fizyczne ${ }^{26}$. Dotyczy to szczególnie mężczyzn zatrudnionych w budownictwie, którzy często, przynajmniej formalnie, są niewykwalifikowanymi robotnikami. W efekcie tworzy się pewien stereotypowy wizerunek, który podzielany jest zarówno przez Norwegów, jak i Polaków - typowa polska rodzina, mężczyzna na budowie, a kobieta sprzq-

${ }^{23}$ Dane pochodzą z oficjalnej strony Norweskiego Dyrektoriatu do Spraw Imigracji.

${ }^{24}$ Informacja na ten temat pojawiła się na spotkaniu zarządu Klubu Polskiego w Norwegii, które autorka obserwowała za zgodą uczestniczących w niej osób (12 czerwca 2019 r.).

${ }^{25}$ H. Haakestad, J.H. Friberg, Deskilling revisited: Labour migration, neo-Taylorism and the degradation of craft work in the Norwegian construction industry, „Economic and Industrial Democracy” 2017, grudzień, https://doi.org/10.1177/0143831X17735671.

${ }^{26}$ Jon Horgen Friberg wskazał, że 82\% Polaków pracujących w Norwegii wykonuje prace fizyczne - za: B. Lindahl, Polish immigrants in Norway - with only one foot in the labour market, 2017, 22 Jun, http://www.nordiclabourjournal.org. 
ta - jak autoironicznie posumował swoją sytuację młody mężczyzna z wyższym wykształceniem ${ }^{27}$.

W strukturze demograficznej zauważalna jest dysproporcja między liczbą kobiet i mężczyzn. To zjawisko częściowo tłumaczyć mogą wspomniane wcześniej obowiązujące do 2009 r. ograniczenia w dostępie do norweskiego rynku pracy, które bardziej uderzały w kobiety. Trudniej niż mężczyznom było im znaleźć zatrudnienie w pełnym wymiarze czasu, $\mathrm{z}$ wynagrodzeniem takim jak norwescy pracownicy, a to właśnie stanowiło podstawę do uzyskania zezwolenia na pobyt ${ }^{28}$. I chociaż z czasem liczba rezydentek rosła, rozbieżność w proporcjach płci utrzymuje się nadal (wykres 9). Jednym z wyjaśnień takiej sytuacji może być to, że norweski rynek pracy charakteryzuje się bardzo wysokim poziomem segregacji ze względu na płeć29. Polakom rejestrowaną pracę łatwiej jest znaleźć w tzw. męskim sektorze, a praca wykonywana przez kobiety często ma miejsce w szarej strefie. Wprawdzie Polki mogły i część z nich korzystała z w pełni sformalizowanych możliwości przyjazdu do Norwegii na podstawie procedury łączenia rodzin czy podjęcia zarejestrowanej pracy ${ }^{30}$ albo nauki, to $\mathrm{w}$ dużym stopniu ich migrację kształtował nieformalny charakter wykonywanych prac, niestabilne i nisko płatne zatrudnienie ${ }^{31}$. Polki sprzątające w Norwegii (w sposób rejestrowany i w szarej strefie) to bardzo zróżnicowana pod względem wykształcenia kategoria pracowników ${ }^{32}$.

Biorąc pod uwagę wykształcenie, w 2018 r. około połowa (48\%) polskich migrantów w wieku 16 lat $\mathrm{i}$ więcej miała średnie, a prawie $1 / 3$ wyższe wykształcenie ${ }^{33}$. Wśród Polaków w wieku 20-66 lat, którzy byli zatrudnieni w IV kwartale

${ }^{27}$ Fragment rozmowy z rodzicami oczekującymi na dzieci po uroczystości zakończenia roku szkolnego przed budynkiem szkoły, w której odbywa się katecheza po polsku (czerwiec 2019 r.).

${ }^{28}$ J.H. Friberg, Culture at work, op. cit.

${ }_{29}$ M.L. Baba, C. Dahl-Jørgensen, Work migration from Poland to Norway, op. cit.

30 Warto przywołać przykład pielęgniarek, które sprowadzane były z Polski w latach 2001-2004 za pośrednictwem agencji pracy, na podstawie specjalnego programu. Zainteresowanie tą propozycją było jednak znacznie mniejsze niż zakładane przez Norwegów. Wyemigrowało zaledwie 190 kobiet. J. Napierała, Sytuacja Polek na rynkach pracy w Danii i Norwegii w okresie poakcesyjnym, „Studia Migracyjne - Przegląd Polonijny” 2010, nr 4, s. 116.

${ }^{31}$ I. Main, I. Czerniejewska, Post-accession Female Mobility between Poland and Norway. New Trends and New Ways of Thinking about Migration, „Sprawy Narodowościowe” 2017, nr 49, https://doi.org/10.11649/sn.1358.

${ }_{32}$ M. Bivand Erdal, Praca i rodzina: Rozważania o powrocie wśród Polaków mieszkających w Norwegii, „Studia Migracyjne - Przegląd Polonijny” 2014, nr 2.

${ }^{33}$ W bazie danych Statistics Norway informacje dotyczące poziomu wykształcenia imigrantów w wieku 16 lat i więcej uwzględniają Międzynarodową Standardową Klasyfikację Kształcenia - ISCED. Zatem w 2018 r. połowa spośród Polaków z wyższym wykształceniem ukończyła studia licencjackie lub ich odpowiedniki (poziom 6), a połowa studia magisterskie lub ich odpowiedniki oraz studia doktoranckie lub ich odpowiedniki (poziom 7-8). 


\section{Wykres 9. Polscy imigranci oraz osoby urodzone w Norwegii, których rodzice pochodzą z Polski, stan na 1 stycznia 2019 r.}

67 lat i więcej
50-66 lat
$40-49$ lat
$30-39$ lat
20-29 lat
$16-19$ lat
13-15 lat
$6-12$ lat
0 -5 lat

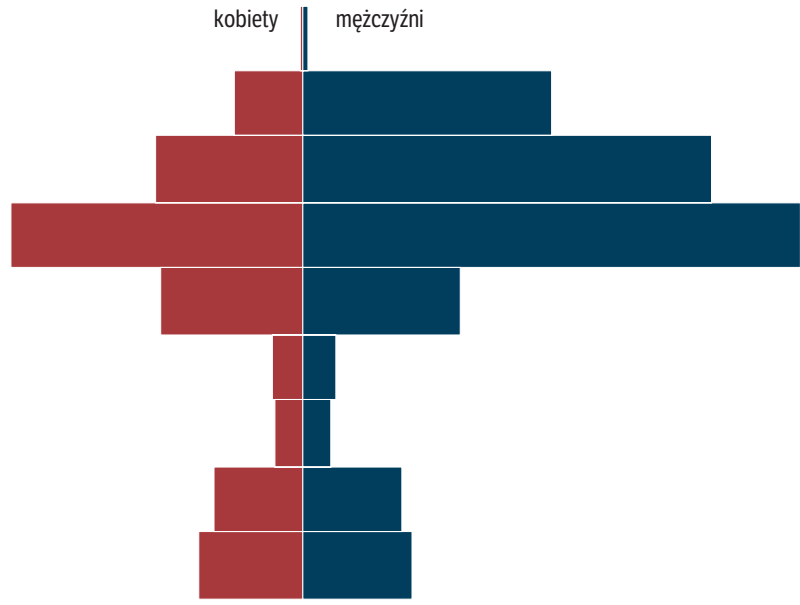

15000

10000

5000

$0 \quad 5000$

10000

$15000 \quad 20000$

25000

Źródło: jak pod wykresem 1.

2018 r., aż 66\% miało wyższe wykształcenie - uwzględniając podział na płeć, $59 \%$ zatrudnionych kobiet i 70\% mężczyzn ${ }^{34}$. Wśród zatrudnionych kobiet 35\% ukończyło studia licencjackie lub ich odpowiedniki, a 24\% magisterskie lub ich odpowiedniki oraz doktoranckie lub ich odpowiedniki. W przypadku mężczyzn odpowiednio było to $57 \%$ i $13 \%$

Chociaż Polacy różnią się stopniem religijności, to przynajmniej dla znacznej części z nich istotną rolę odgrywa Kościół rzymskokatolicki, który w Norwegii jest kościołem mniejszościowym ${ }^{35}$. Co więcej, dla Norweskiego Dyrektoriatu do Spraw Imigracji (UDI) Kościół rzymskokatolicki to odpowiedni pośrednik w kontaktach z polskimi imigrantami, którzy w stosunku do urzędów oraz osób spoza najbliższego kręgu rodziny i znajomych są podejrzliwi i zachowują dystans. Jako migranci zarobkowi Polacy nie są objęci w Norwegii indywidualnymi programami integracyjnymi, dlatego Kościołowi przekazywane są środki finansowe na wsparcie ich integracji przez organizowanie spotkań informacyj-

${ }^{34}$ Także w tych tabelach Norweski Urząd Statystyczny stosuje ISCED. Zatem studia licencjackie lub ich odpowiedniki ukończyło 49\% Polaków w wieku 20-66 lat, którzy byli zatrudnieni w czwartym kwartale 2018 r. Studia magisterskie lub ich odpowiedniki oraz studia doktoranckie lub ich odpowiedniki $17 \%$.

35 Siedemdziesiąt procent ludności Norwegii to członkowie Kościoła luterańskiego (Den Norske Kirke). Rozdział Kościoła luterańskiego od państwa nastąpił w Norwegii dopiero w $2017 \mathrm{r}$. 
nych, porad prawnych itp. ${ }^{36}$. Prawie połowa spośród 157 tys. (koniec 2018 r.) członków Kościoła rzymskokatolickiego to imigranci z Polski i Litwy ${ }^{37}$, a w latach 2010-2015 utworzono 13 nowych stanowisk dla księży polskojęzycznych ${ }^{38}$. Duchowni poza posługą religijną często wykonują zadania pracowników socjalnych. Poszczególne parafie organizują polskie wydarzenia, są miejscami spotkań towarzyskich, zdobywania ważnych informacji na temat pracy, mieszkania, uprawnień socjalnych itp. Jednak tendencja do tworzenia równoległego do norweskiego duszpasterstwa polskiego napotyka pewne opory ze strony Polaków, którzy wcześniej przyjechali i zintegrowali się z norweskim społeczeństwem ${ }^{39}$. Oczekiwania imigrantów z dłuższym stażem (nazwijmy ich przedakcesyjnymi) wpisują się poniekąd w oczekiwania Norwegów. Polacy nie są przez nich postrzegani jako „aż tak różni” od nich w porównaniu z migrantami z Azji czy Afryki. Zatem przy odpowiedniej polityce ze strony państwa norweskiego w drugim czy trzecim pokoleniu powinni się wtopić w norweskie społeczeństwo $^{40}$. Badacze wskazują jednak, że Polacy dalecy są od norweskich standardów, szczególnie jeżeli chodzi o zaangażowanie w życie publiczne. Chociaż stanowią największą grupę imigrancką, to zarejestrowane polskie organizacje są wciąż nieliczne, a członkostwo w nich czy szerzej - zaangażowanie obywatelskie to raczej domena aktywistów. Główny filar zorganizowanych działań społecznych stanowią: udział w nabożeństwach, tradycyjnych uroczystościach, lekcjach języka polskiego i/lub katechezy dla dzieci, a także praktyczna pomoc dla nowo przybyłych imigrantów ${ }^{41}$.

\section{Niekorzystne uwarunkowania funkcjonowania Polaków na norweskim rynku pracy}

Ze względu na ograniczoną objętość artykułu spośród ważnych zagadnień wybrano kwestię funkcjonowania Polaków na norweskim rynku pracy, a dokładniej jego niekorzystne uwarunkowania. Wybór uzasadniony jest tym, że chociaż

${ }_{36}$ E. Guribye, P. Pustulka, M. Ślusarczyk, B. Zyzak, Left to their own devices? On the role of Polish migrant organisations [w:] Transnational Polish families in Norway: Social capital, integration, institutions and care, eds. K. Slany, P. Pustulka, E. Guribye, M. Ślusarczyk, Peter Lang, Frankfurt am Main, New York 2018, https://doi.org/10.3726/978-3-653-06594-7. Nieufności migrantów wobec osób spoza najbliżej rodziny, krewnych i przyjaciół nie można rozpatrywać w oderwaniu od całego społeczeństwa polskiego, które charakteryzuje niski stopień zaufania społecznego, zob. „Diagnoza Społeczna 2015” red. J. Czapiński, T. Panek, ww.diagnoza.com.

37 O. Hovdelien, The Roman Catholic Church of Norway and migration challenges, „International Journal for the Study of the Christian Church" 2019, Vol. 19(1), s. 18, https://doi. org/10.1080/1474225x.2019.1580953.

38 Ibidem, s. 24.

39 Ibidem, s. 27.

40 M. Sokół-Rudowska, Us among them, op. cit.

${ }^{41}$ E. Guribye, P. Pustulka, M. Ślusarczyk, B. Zyzak, Left to their own devices?, op. cit. 
wskaźnik zatrudnienia wśród imigrantów z Polski jest wyższy niż wśród samych Norwegów ${ }^{42}$, to migracje zarobkowe z Europy Środkowej i Wschodniej stanowią wyzwanie dla egalitarności norweskiego rynku pracy. Obawy dotyczą omijania lub wręcz łamania przez pracodawców istniejących przepisów w celu uzyskania przewagi konkurencyjnej, opierającej się na niskim wynagrodzeniu pracowników zagranicznych i nieprzestrzeganiu zasad bezpieczeństwa i higieny pracy. Niepokój budzą skutki takiej konkurencji na formowanie się wynagrodzeń, na układy zbiorowe pracy oraz funkcjonowanie przedsiębiorstw ${ }^{43}$. Temat wydaje się tym istotniejszy, że pierwsze pokolenie polskich migrantów do życia w Norwegii adaptuje się głównie przez rynek pracy, gdyż jako migranci zarobkowi nie są objęci indywidualnymi programami integracyjnymi. Co więcej, różnice w wynagrodzeniach między Polską i Norwegią sprawiają, że Polacy przystają na warunki, które dla Norwegów są nie do zaakceptowania. Badacze wskazują, że problemy komunikacyjne są ważnym czynnikiem sprzyjającym powstawaniu etnicznych nisz na rynku pracy oraz tworzeniu polskich enklaw w Norwegii ${ }^{4}$.

Wyrazistej ilustracji dostarcza sektor budowlany. W związku z obecnością cudzoziemskich pracowników (głównie Polaków i Litwinów niemówiących po norwesku) maleje zainteresowanie ze strony norweskiej młodzieży zdobywaniem kwalifikacji i pracą w budownictwie, która utożsamiana jest $\mathrm{z}$ zajęciem dla imigrantów. Sektor uzależnił się od zagranicznej siły roboczej, a jego produktywność spadła. Zaburzeniu uległ tradycyjny system, zakorzeniony w silnej tradycji rzemieślniczej. Pozycja wyszkolonych pracowników budowlanych została zdegradowana, obniżyły się ich wynagrodzenia, pogorszyły warunki pracy, zaburzeniu uległy społeczne relacje ze współpracownikami i kierownictwem. Norwescy badacze upatrują $\mathrm{w}$ tym zagrożenia dla wykwalifikowanej pracy w budownictwie i produktywności także w przyszłości ${ }^{45}$. W opisanej sytuacji niewątpliwym wygranym są agencje pracy czasowej, które nie tylko zdominowały rynek budowlany w Norwegii, ale czerpały korzyści z samego faktu zatrudnienia pracowników zagranicznych, oferując im umowy bez wynagrodzenia w czasie choroby lub/i urlopu wypoczynkowego. Oprócz łamania zasad dotyczących czasu pracy i nadgodzin nie dbały też o warunki pracy na placach budowy oraz nie organizowały szkoleń.

${ }^{42}$ K.R. Tronstad, M. Nygaard, M. Bask, Accumulation of welfare problems, op. cit., s. 31.

${ }^{43}$ J.H. Friberg i in., Nordic labour market institutions and new migrant workers: Polish migrants in Oslo, Copenhagen and Reykjavik, „European Journal of Industrial Relations” 2014, Vol. 20(1), https://doi.org/10.1177/0959680113516847.

44 J.H. Friberg, K.R. Tronstad, J.E. Dølvik, Central and Eastern European labour migration to Norway: trends, conditions and challenges [w:] Free Movement of Workers and Labour Market Adjustment: Recent Experiences from OECD Countries and the European Union, OECD Publishing, 2012, pdf, https://doi.org/10.1787/9789264177185-9-en; M. Sokół-Rudowska, Us among them, op. cit.

${ }^{45}$ H. Haakestad, J.H. Friberg, Deskilling revisited: Labour migration, op. cit. 
Pod naciskiem związków zawodowych państwo norweskie w ostatnim czasie podjęło działania, które mają zapobiec tym nieuczciwym praktykom. Istotne wydaje się to, że za zmianami w prawie opowiedziały się wszystkie partie w norweskim parlamencie. Od początku 2019 r. obowiązują bardziej restrykcyjne przepisy regulujące działalność branży pośrednictwa pracy ${ }^{46}$. Niemniej już po wejściu w życie nowych przepisów kontrola przeprowadzona na własnych projektach przez Statsbygg - państwową spółkę odpowiedzialną za realizację rządowej polityki dotyczącej budownictwa i nieruchomości, głównego doradcę rządu do spraw budownictwa, ale także instytucję budującą na potrzeby sektora publicznego - wykazała, że agencje w umowach z pracownikami zaniżały wymiar etatu i wciąż nie precyzowały czasu pracy ${ }^{47}$.

Także branżę sprzątającą, w której znaczną część pracowników stanowią imigranci z Polski ${ }^{48}$, objęto od 2018 r. surowszymi przepisami. Skalę nieprawidłowości przedstawił raport opublikowany przez Arbeidstilsynet (Norweska Inspekcja Pracy) dotyczący zarejestrowanych firm sprzątających, a obejmujący lata 2013-2017. Wykazał, że 75\% z firm nie spełniało norm przewidzianych w prawie pracy ${ }^{49}$. Jednak nawet po wprowadzeniu zmian nadużycia nie zostały całkowicie wyeliminowane, a bardziej narażone na nie były osoby urodzone poza Norwegią ${ }^{50}$.

Polscy migranci opisując doświadczenia swoje i innych, przywołują także przykłady nadużyć ze strony rodaków ${ }^{51}$. Wśród nich wymienia się brak jasnych umów albo prace na czarno. Wspominano opóźnienia i celowe wstrzymywanie czy zaniżanie wynagrodzenia szczególnie za nadgodziny oraz brak wynagrodzenia $\mathrm{w}$ trakcie urlopu czy/i choroby. Wymieniano też bezpodstawne potrącenia $\mathrm{z}$ wynagrodzenia za rzekome usługi ze strony pracodawcy, np. przy uzyskaniu numeru identyfikacyjnego przyznawanego obcokrajowcom, za transport do miejsca wykonywania pracy czy sprzęt i odzież roboczą. Zdarzały się przypadki przejmowania

${ }^{46}$ M. Zych, Nowe przepisy najmu pracowników. Szef związków zawodowych: „to krok $w$ dobra stronę", 5 lutego 2019 r., www.mojanorwegia.pl.

47 Ibidem.

48 Bazy danych Statistics Norway zawierają informacje na temat imigrantów z Polski zatrudnionych przy sprzątaniu i pracach porządkowych (cleaners and helpers). W latach 2015-2018, w IV kwartale było ich odpowiednio 6208, 6399, 6613 i 6649.

49 Za: K. Łukowicz, Trzy czwarte firm sprzątających nie przeszło kontroli. Grzechem głównym zatrudnianie na czarno, 10 stycznia 2018 r., www.mojanorwegia.pl.

${ }^{50}$ M. Pianowska, Branża sprzatająca wcią̇̇ z tyłami: co trzecia osoba nie dostaje bonusu $z a$ „nocki”, kuleją opłaty za dojazd, 10 września 2018 r., www.mojanorwegia.pl.

${ }^{51}$ Akapit opiera się na informacjach $\mathrm{z}$ wywiadów, które autorka zebrała latem 2018 i 2019 r. (15 wywiadów z 18 osobami). Poza wywiadem przeprowadzonym w związkach zawodowych nie były one bezpośrednio związane z rynkiem pracy. Opisy nadużyć pojawiały się u części rozmówców jako odpowiedź na pytanie: Jak to się stało, że znaleźli się w Norwegii i/albo jak im się tu żyje? Uwagami na temat nieuczciwych praktyk migranci dzielili się także przy okazji nieformalnych rozmów. Wątki dotyczące tej kwestii pojawiały się też w komentarzach na portalu www.mojanorwegia.pl. 
przez pracodawcę zwrotu nadpłaconego przez pracownika podatku. Wydłużaniu czasu pracy z pogwałceniem norweskich regulacji towarzyszyło oczekiwanie bezwzględnej dyspozycyjności ze strony pracownika oraz nieprzestrzeganie zasad bezpieczeństwa i higieny pracy. W przypadku lączenia pracy z zamieszkaniem kwatery (które często nie spełniały norm) wynajmowano pracownikom za zawyżone stawki. Kobiety sprzątające w prywatnych mieszkaniach wspominały o płaceniu osobie pośredniczącej w znalezieniu klientów. Opłata mogła być jednorazowa (tzw. odsprzedanie domków czy grafiku) lub wnoszona co miesiąc z pieniędzy otrzymanych od klientów. Polacy przyczyniając się do utrzymywania rodaków w szarej strefie, jednocześnie czerpali korzyści finansowe z nieuregulowanego stosunku pracy. Część miała oficjalnie działające firmy sprzątające, a na wykonywanie usług podpisane umowy nie tylko z osobami prywatnymi, ale także z przedsiębiorstwami czy innymi instytucjami. Jednak tylko część pracowników zatrudniona była formalnie i/lub rejestrowane usługi stanowiły zaledwie część działalności.

Do nadużyć dochodziło także w relacjach między pracownikami. Na pogłębione badania zasługuje rola dobrze zaadoptowanych do norweskich realiów Polaków, którzy pośredniczą w kontaktach między polskimi pracownikami nieznającymi języków obcych oraz norweskiego prawa i porządku instytucjonalnego a agencjami pracy czasowej czy kadrą kierowniczą i pracodawcami w innych przedsiębiorstwach ${ }^{52}$. Zaniżanie stawek i zgoda na wydłużanie czasu pracy to także przyczyna rosnącego antagonizmu między Polakami. Ci, którym towarzyszą rodziny, zainteresowani są osiąganiem jak najwyższych dochodów przy zachowaniu równowagi między czasem poświęconym na pracę i rodzinę $e^{53}$. Taki antagonizm można odnaleźć także w dyskusjach w mediach społecznościowych i komentarzach na portalach.

Specjalna uwaga poświęcona kwestii pracy związana jest też z tym, że projekty migracyjne osób przebywających w Norwegii z rodzinami często mają cechy wspólne z projektami migracyjnymi robotników-gości z lat 60., np. Turków, którzy przybyli do Niemiec, a którzy mimo planów powrotu od ojczyzny takiego powrotu nie urzeczywistnili ${ }^{54}$.

\section{Podsumowanie}

Po wstąpieniu Polski do UE liczba Polaków w Norwegii zaczęła dynamicznie wzrastać i są oni dzisiaj największą grupą imigrancką w tym kraju, przy czym

52 Podczas wywiadu (24 czerwca 2019 r.), który autorka przeprowadziła z Mirosławem Bartnikiem, pracownikiem Fellesforbundet (związek zawodowy, który jest częścią Norweskiej Konfederacji Związków Zawodowych), zwrócił on uwagę, że wraz ze wzrostem liczby Polaków zatrudnionych na stanowiskach biurowych w agencjach pracy czasowej wzrosła liczba nieprawidłowości w stosunku do robotników.

${ }^{53}$ K. Gmaj, „Oswajanie” Norwegii, op. cit.

${ }^{54}$ M. Bivand Erdal, Praca i rodzina, op. cit. 
połowa mieszka w Norwegii pięć i więcej lat. Wszystko wskazuje na to, że obecność Polaków na stałe wpisała się w norweski krajobraz i że czasowa migracja przybiera formę długotrwałego pobytu, chociaż typowa migracja osiedleńcza, tzn. planowana migracja jednostki lub całej rodziny w celu zmiany miejsca do życia, wydaje się raczej wyjątkową sytuacją. Niemniej dominujący po $2004 \mathrm{r}$. wzór czasowych migracji uzupełniany jest przez długookresowe migracje rodzinne. W tym kontekście rysuje się więc podobieństwo ze wzorami obserwowanymi w Wielkiej Brytanii i Irlandii. Zatem procesy migracyjne i adaptację polskich migrantów w Norwegii lepiej poznać jest w kontekście różnych stadiów procesu migracyjnego niż różnych kategorii migrantów.

Przekrój zawodowy Polaków w dużym stopniu odzwierciedla popyt na siłę roboczą. Zatrudnieni są głównie w następujących sektorach gospodarki: budownictwo, energia elektryczna, zaopatrzenie w wodę, kanalizacja, gospodarka odpadami; produkcja; rekrutacja pracowników i zapewnienie personelu. Na różnych stanowiskach odnaleźć ich też można w służbie zdrowia, edukacji czy administracji i usługach. Najczęściej jednak wykonują prace fizyczne, które nie muszą wiązać się z ich wykształceniem czy pracą wykonywaną w Polsce. Chociaż Polacy zróżnicowani są pod względem religijności, trudno nie zauważyć, że to oni wpływają na zwiększenie się liczby rzymskich katolików, którzy w Norwegii należą do mniejszości wyznaniowej. Jeśli chodzi o strukturę demograficzną, to cechuje się ona nadreprezentacją mężczyzn w stosunku do liczby kobiet, szczególnie widoczną w grupie wieku 30-66 lat. Co ciekawe, Polacy są grupą imigrantów z najwyższym odsetkiem osób mieszkających na obszarach słabo zaludnionych. Jednak ponad połowa polskich migrantów mieszka w czterech okręgach znajdujących się w południowej części kraju: Oslo, Akershus, Rogeland, Hordaland.

To, że adaptacja migrantów z Polski odbywała się głównie za pośrednictwem rynku pracy, było powodem nadużyć wobec nich. Co więcej, masowemu napływowi pracowników z Europy Środkowej i Wschodniej towarzyszyło pogarszanie pozycji szeregowego pracownika i wzmacnianie pozycji pracodawcy oraz kadry kierowniczej, a także rozwój szarej strefy. Przedsiębiorstwa chcące zachować wobec zatrudnionych wysokie standardy stawały się mniej konkurencyjne. Zatem negatywne konsekwencje dotyczyły nie tylko funkcjonowania poszczególnych migrantów, ale także norweskiej gospodarki, stanowiąc zagrożenie dla dotychczasowego modelu stosunków pracy.

Uwzględniając argumenty przedstawione w artykule, można wskazać, że w przyszłości baczniejszą uwagę badaczy skupić warto na funkcjonowaniu Polaków na rynku pracy. Szczególnie ważna wydaje się kwestia mobilności zawodowej Polaków związana ze zmianą pracodawcy lub statusu zawodowego migranta. Analizy powinny obejmować perspektywę mobilności zawodowej związanej ze zmianami w ramach tego samego miejsca pracy oraz dotyczącą mobilności między zawodami i pracodawcami. Interesującą kwestią są efekty zmian prawnych i kontroli przeprowadzanych w miejscach pracy. W założe- 
niu mają one przeciwdziałać wykorzystywaniu pracowników, w tym przede wszystkim pracowników zagranicznych, i przywrócić konkurencyjność przedsiębiorstw dobrze traktujących zatrudnionych. Na uwagę zasługuje ponadto sytuacja młodych ludzi, którzy uczyli się w Norwegii i zaczynają wchodzić na tamtejszy rynek pracy.

\section{Bibliografia}

Baba M.L., Dahl-Jørgensen C., Work migration from Poland to Norway: A new institutional approach, ,iNtergraph: journal of dialogic anthropology” 2010, No 2(2).

Bell J., Bivand Erdal M., Transnational family life among Polish migrants in Norway: Limited, but enduring transnational ties?, „Studia Migracyjne - Przegląd Polonijny” 2015, nr 3.

Burkiewicz Ł., Rozwój katolicyzmu w protestanckim kraju. Polacy w Norwegii, „Posłaniec” 2010, nr 10.

„Diagnoza Społeczna 2015” red. J. Czapiński, T. Panek, www.diagnoza.com.

Bivand Erdal M., Praca i rodzina: Rozważania o powrocie wśród Polaków mieszkających w Norwegii, „Studia Migracyjne - Przegląd Polonijny” 2014, nr 2.

Friberg J.H., Culture at work: Polish migrants in the ethnic division of labour on Norwegian construction sites, „Ethnic and Racial Studies” 2012, Vol. 35(11), https://doi.org/10. 1080/01419870.2011.605456.

Friberg J.H., Tronstad K.R., Dølvik J.E., Central and Eastern European labour migration to Norway: trends, conditions and challenges [w:] Free Movement of Workers and Labour Market Adjustment: Recent Experiences from OECD Countries and the European Union, OECD Publishing, 2012, pdf, https://doi.org/10.1787/9789264177185-9-en.

Friberg J.H. i in., Nordic labour market institutions and new migrant workers: Polish migrants in Oslo, Copenhagen and Reykjavik, „European Journal of Industrial Relations” 2014, Vol. 20(1), https://doi.org/10.1177/0959680113516847.

Gmaj K., „Oswajanie” Norwegii: wzory osiedleńcze polskich migrantów w Norwegii, „Studia Migracyjne - Przegląd Polonijny” 2018, nr 1(167), https://doi.org/10.4467/254 44972smpp.18.008.8917.

Gmaj K., Settling in Norway? The case of Polish migrants and their families, „Myśl Ekonomiczna i Polityczna" 2016, nr 2.

Gmaj K., Iglicka K., The Story of the Icy Paradise: Polish Migration to Norway after the EU Enlargement (2004) in the Light of Research and Statistical Data, „CBU International Conference Proceedings” 2018, Vol. 6, https://doi.org/10.12955/cbup.v6.1149.

Godzimirski J., Stormowska M., Dudzińska K., Nowe diaspory w Europie i zarządzanie migracja: Przypadek Polaków w Norwegii, Polski Instytut Spraw Międzynarodowych, Instytut Studiów Politycznych Polskiej Akademii Nauk, Norweski Instytut Spraw Międzynarodowych, Warszawa 2015.

Guribye E., Pustulka P., Ślusarczyk M., Zyzak B., Left to their own devices? On the role of Polish migrant organisations [w:] Transnational Polish families in Norway: Social capi- 
tal, integration, institutions and care, eds. K. Slany, P. Pustulka, E. Guribye, M. Ślusarczyk, Peter Lang, Frankfurt am Main, New York 2018, https://doi.org/10.3726/9783-653-06594-7.

Haakestad H., Friberg J.H., Deskilling revisited: Labour migration, neo-Taylorism and the degradation of craft work in the Norwegian construction industry, „Economic and Industrial Democracy” 2017, grudzień, https://doi.org/10.1177/0143831X17735671.

Hovdelien O., The Roman Catholic Church of Norway and migration challenges, „International Journal for the Study of the Christian Church" 2019, Vol. 19(1), https://doi. org/10.1080/1474225x.2019.1580953.

Huang L., Kochowicz M., Krzaklewska E., Pustulka P., TRANSFAM Web-survey on Polish families living in Polish-Norwegian transnationality Documentation of design, variables and measures, 2015, http://www.transfam.socjologia.uj.edu.pl.

Huang L., Krzaklewska E., Pustulka P., Young Polish migrants in Norway: Education, work and settlement choice, „Tidsskrift For Ungdomsforskning” 2016, Vol. 16 (1).

Iglicka K., Gmaj K., Wierzejski A., Contextualizing Polish Migration to Norway in the light of theory, statistical data and research findings [w:] Transnational Polish families in Norway: Social capital, integration, institutions and care, eds. K. Slany, P. Pustulka, E, Guribye, M. Ślusarczyk, Peter Lang, Frankfurt am Main, New York 2018, https:// doi.org/10.3726/978-3-653-06594-7.

Iglicka K., Powroty Polaków po 2004 roku. W pętli pułapki migracji, Scholar, Warszawa 2010.

Łukowicz K., Trzy czwarte firm sprzątajacych nie przeszło kontroli. Grzechem głównym zatrudnianie na czarno, 10 stycznia 2018 r., www.mojanorwegia.pl.

Main I., Czerniejewska I., Post-accession Female Mobility between Poland and Norway. New Trends and New Ways of Thinking about Migration, „Sprawy Narodowościowe” 2017, nr 49, https://doi.org/10.11649/sn.1358.

Napierała J., Sytuacja Polek na rynkach pracy w Danii i Norwegii w okresie poakcesyjnym, „Studia Migracyjne - Przegląd Polonijny” 2010, nr 4.

Pianowska M., Branża sprzątająca wciąż z tyłami: co trzecia osoba nie dostaje bonusu za „nocki”, kuleją opłaty za dojazd, 10 września 2018 r., www.mojanorwegia.pl.

Pianowska M., Zdelegalizować agencje pracy: związki zawodowe i politycy łączą siły w manifestacji, 15 listopada 2017 r., www.mojanorwegia.pl.

Sokól-Rudowska M., Us among them: A study of the contemporary Polish emigration to Norway, „Studia Humanistyczne AGH” 2013, t. 12/1, https://doi.org/10.7494/ human.2013.12.1.9.

Ślusarczyk M., Wardhal R., Strzemecka S., Polish children and their parents adapting to new school reality in Norway [w:] Transnational Polish families in Norway: Social capital, integration, institutions and care, eds. K. Slany, P. Pustulka, E. Guribye, M. Ślusarczyk, P. Lang, Frankfurt am Main, New York 2018, https://doi.org/10.3726/9783-653-06594-7.

Thorud E., Stabbetorp L., Galloway T., Hårstad-Fonn K., International Migration 20132014 - IMO report for Norway, Norwegian Ministry of Education and Research, 
Norwegian Ministry of Children, Equality and Social Inclusion, Norwegian Ministry of Justice and Public Security, Norwegian Ministry of Labour, 2014, pdf.

Tronstad K.R., Nygaard M., Bask M., Accumulation of welfare problems among immigrants in Norway, NIBR, OsloMet, Oslo 2018.

Waerdahl R., Integration and re-integration of Polish children in school: Part 1. Inclusion of Polish children in Norwegian schools, (WP7 Working Report), 2015, http://www. transfam.socjologia.uj.edu.pl.

White A., Polish Families and Migration since EU accession, Policy Press, Bristol 2011.

Zych M., Nowe przepisy najmu pracowników. Szef związków zawodowych: „to krok w dobra strone", 5 lutego 2019 r., www.mojanorwegia.pl.

\section{Źródła internetowe}

MojaNorwegia.pl: portal dla Polaków w Norwegii, www.mojanorwegia.pl.

Norweski Dyrektoriat do spraw Imigracji, https://www.udi.no/.

Norweski Urząd Statystyczny, Statistics Norway (Statistisk sentralbyrå), https://www. ssb.no. 